Brazilian Journal of Animal Science ISSN 1806-9290

www.rbz.org.br

Brasileira de Zootecnia

*Corresponding author:

a_monteiro@zootecnista.com.br

Received: June 27, 2018

Accepted: August 26, 2018

How to cite: Somensi, M. L.; Monteiro, A. N. T. R. Bockor, L.; Marx, F. R.; Vieira, M. S. and Kessler, A. M. 2019. Availability of betaine present in fine wheat bran in diets for growing pigs. Revista Brasileira de Zootecnia 48:e20180141. https://doi.org/10.1590/rbz4820180141

Copyright: This is an open access article distributed under the terms of the

Creative Commons Attribution License

(http://creativecommons.org/licenses/by/4.0/), which permits unrestricted use, distribution, and reproduction in any medium, provided the original work is properly cited.

\section{Availability of betaine present in fine wheat bran in diets for growing pigs}

\author{
Marcelo Luiz Somensi ${ }^{1}$ (iD, Alessandra Nardina Trícia Rigo Monteiro ${ }^{1^{*}}$ iD, \\ Luciane Bockor $^{1}$ (iD), Fábio Ritter Marx ${ }^{1}$ (iD), Marcia de Souza Vieira ${ }^{1}$ (iD), \\ Alexandre de Mello Kessler ${ }^{1}$ iD \\ ${ }^{1}$ Universidade Federal do Rio Grande do Sul, Faculdade de Agronomia, Departamento de \\ Zootecnia, Porto Alegre, RS, Brasil.
}

\begin{abstract}
The objective of this paper was to investigate the availability of betaine present in fine wheat bran (FWB) in diets for growing pigs. We used thirty crossbred intact males, housed individually in metabolic cages and distributed in a randomized block design, with five treatments and six replicates. Blocks consisted of two periods of 15 days. Average initial body weights were $32.00 \pm 1.30$ and $44.90 \pm 1.32 \mathrm{~kg}$, in the first and second periods, respectively. Treatments were modified only at the level of methionine plus cysteine (Met+Cys) required and the Met+Cys sources, consisting of a negative control (NC), formulated with $80 \%$ of Met+Cys requirements, and four positive controls (PC): $\mathrm{PC}_{\text {Met }}$ - NC supplemented with $1.2 \mathrm{~g} \mathrm{~kg}^{-1}$ of DL-methionine; $\mathrm{PC}_{\text {Bet }}-\mathrm{NC}$ supplemented with $0.9 \mathrm{~g} \mathrm{~kg}^{-1}$ of anhydrous betaine; $\mathrm{PC}_{\mathrm{FWB}}$ - diet formulated with $\mathrm{FWB}$; and $\mathrm{PC}_{\mathrm{FWB}+\mathrm{Met}}-\mathrm{PC}_{\mathrm{FWB}}$ supplemented with $1.0 \mathrm{~g} \mathrm{~kg}^{-1}$ of DL-methionine. No differences were observed on performance-related variables or on the digestibility coefficient of dry matter. Conversely, the digestibility coefficient of crude energy was lower when pigs were fed FWB and could be associated to the higher fiber content of FWB feeds. Digestible energy of feeds was higher for FWB diets, while the metabolizable energy of FWB diets did not differ from $\mathrm{PC}_{\mathrm{Met}}$ and $\mathrm{PC}_{\mathrm{Bet}}$ Nitrogen intake and apparent absorption were lower when pigs were fed FWB, but nitrogen retention, protein utilization, and biological value of the feed protein were the same among PC treatments, indicating that nitrogen from diets was used by pigs with the same efficiency, and is supported by no differences in performance-related variables. The FWB composition showed $12 \mathrm{~g}$ of betaine $\mathrm{kg}^{-1}$, which is available to maintain nitrogen retention and performance.
\end{abstract}

Keywords: byproduct, methionine, nutrition, swine

\title{
Introduction
}

Methionine, an essential amino acid for pigs, participates in a number of metabolic pathways. It is the primer for protein synthesis, precursor for other amino acids, and an important donor of methyl groups (Nelson and Cox, 2014). Methyl-group transfer reactions are essential for the biosynthesis of several body substances, such as creatine, carnitine, epinephrine, and melatonin (Brosnan et al., 2007).

In transmethylation reactions, methyl groups for remethylation to methionine can be provided by homocysteine, choline, or betaine (Nelson and Cox, 2014). For this reason, betaine is commonly used as an animal feed additive, and its effects as an osmolyte, methyl donor, and carcass modifier have been observed in some studies (Eklund et al., 2005; Feng et al., 2006). 
Due to research on human nutrition, natural betaine was found in some ingredients such as wheat and wheat bran, with content ranging between 1,339 and 1,506 mg/100 g (Zeisel et al., 2003). These findings have provided useful insights into animal nutrition, presenting the question of whether wheat byproducts could be a betaine source. Besides, Wesendonck et al. (2013) already showed that fine wheat bran (FWB) could be incorporated in pig diets, due to its values of metabolizable energy $\left(2,786 \mathrm{kcal} \mathrm{kg}^{-1}\right)$ and digestible protein $\left(124.1 \mathrm{~g} \mathrm{~kg}^{-1}\right)$ (Wesendonck et al., 2013).

Based on this background, FWB could be a promising source of energy and betaine for pigs, but to our knowledge, no information has been published about the availability of the betaine present in this feed ingredient. The objective of this paper was to investigate the availability of betaine present in FWB in diets for growing pigs, using nutrient digestibility and nitrogen balance as responses.

\section{Material and Methods}

Research on animals was conducted according to the institutional committee on animal use (case number 22583). The experiment was carried out in Porto Alegre, Rio Grande do Sul, Brazil $\left(30^{\circ} 01^{\prime} \mathrm{S}\right.$ latitude, $51^{\circ} 13^{\prime} \mathrm{W}$ longitude, and $46 \mathrm{~m}$ elevation).

In this study, we used thirty crossbred intact males (Agroceres $\times$ DanBred), housed individually in metabolic cages and in a partial temperature-controlled room. The animals were distributed in a randomized block design, in which the blocks consisted of two periods of 15 days. Each block (period 1 and 2) was composed by five treatments and three replicates each, totaling six replicates. Average initial body weights were $32.00 \pm 1.30$ and $44.90 \pm 1.32 \mathrm{~kg}$ in the first and second periods, respectively. Each experimental period was divided into five days for adaptation and 10 days for total feces and urine collection.

The treatments were made up of diets formulated to meet the nutritional requirements proposed by Rostagno et al. (2011) for intact growing pigs, nutritionally modified only at the levels of methionine plus cysteine (Met+Cys) and betaine (Table 1). These levels were adjusted by adding methionine and/ or betaine sources (DL-methionine 99\%, anhydrous betaine 96\%, and FWB), maintaining the molar ratio between both sources (1.00:1.27 betaine:methionine).

The negative control (NC) was formulated with $80 \%$ of Met+Cys requirements. The remaining diets were four positive control (PC) diets: $\mathrm{PC}_{\mathrm{Met}}-\mathrm{NC}$ supplemented with $1.2 \mathrm{~g} \mathrm{~kg}^{-1}$ of DL-methionine; $\mathrm{PC}_{\mathrm{Bet}}$ - NC supplemented with $0.9 \mathrm{~g} \mathrm{~kg}^{-1}$ of anhydrous betaine; $\mathrm{PC}_{\mathrm{FWB}}$ - diet formulated with $\mathrm{FWB}$; and $\mathrm{PC}_{\mathrm{FWB}+\mathrm{Met}}-\mathrm{PC}_{\mathrm{FWB}}$ supplemented with $1.0 \mathrm{~g} \mathrm{~kg}^{-1}$ of DL-methionine. Fine wheat bran was subjected to chemical analyses (separation by capillary electrophoresis with UV detection; Eurofins Scientific, Garibaldi, Brazil), and its betaine content was $12 \mathrm{~g} \mathrm{~kg}^{-1}$; so this byproduct contributed $24 \mathrm{~g}$ of betaine $\mathrm{kg}^{-1}$ to the diets $\mathrm{PC}_{\mathrm{FWB}}$ and $\mathrm{PC}_{\mathrm{FWB}+\mathrm{Met}}$

Pigs were fed at 2.6 times the maintenance energy requirement (ARC, 1981) based on their estimate metabolic body weight $\left(\mathrm{BW}^{0.60}\right)$, which was assumed to be $2.6 \times 250 \mathrm{kcal} \mathrm{ME} \times \mathrm{BW}^{0.60}$ dietary $\mathrm{ME}^{-1}$ (Noblet and Shi, 1993). Water was supplied ad libitum and diets were offered in three daily meals (at 08:30, 13:30, and 17:30 h). Total urine and feces of each pigs were collected separately. The beginning and end of each collection were determined by the appearance of marked feces with the addition of $2.5 \mathrm{~g} \mathrm{~kg}^{-1}$ of ferric oxide $\left(\mathrm{Fe}_{2} \mathrm{O}_{3}\right)$ in the diets. Feces were collected twice a day (10:00 and 16:00 h), weighed, packed in plastic bags, and stored in a freezer at $-10{ }^{\circ} \mathrm{C}$. Urine was collected in a bucket via a funnel below the cage. To prevent nitrogen losses by ammonia volatilization, $5 \mathrm{~mL}$ of sulphuric acid $\left(\mathrm{H}_{2} \mathrm{SO}_{4}\right)$ was added to the buckets. The volume was weighed daily, and a $10 \%$ aliquot was removed and refrigerated at $-10^{\circ} \mathrm{C}$.

Feces and urine were dried in a force-ventilation oven at $60{ }^{\circ} \mathrm{C}$ for $72 \mathrm{~h}$. According to AOAC (1990) procedures, the samples were analyzed for dry matter (DM; method 930.15) and nitrogen (method 954.01). Crude energy (CE) was analyzed by bomb calorimetry (IKA Werke GmbH and Co. KG, Staufen, Germany). According to the calculation described by Sakomura and Rostagno (2016), the digestibility coefficients of DM (DCDM) and CE (DCCE) were calculated. Digestible energy (DE) and metabolizable energy (ME) of feeds were calculated as described by Campbell et al. (1983). 
Table 1 - Ingredients and chemical composition of diets

\begin{tabular}{|c|c|c|c|c|c|}
\hline \multirow{2}{*}{ Item } & \multicolumn{5}{|c|}{ Treatment $^{1}$} \\
\hline & NC & $\mathrm{PC}_{\text {Met }}$ & $\mathrm{PC}_{\text {Bet }}$ & $\mathrm{PC}_{\mathrm{FWB}}$ & $\mathrm{PC}_{\mathrm{FWB}+\mathrm{Met}}$ \\
\hline \multicolumn{6}{|l|}{ Ingredient ( $\mathrm{g} \mathrm{kg}^{-1}$ as fed) } \\
\hline Maize & 362 & 362 & 362 & 290 & 290 \\
\hline Soybean meal & 299 & 299 & 299 & 241 & 241 \\
\hline Corn starch & 217 & 217 & 217 & 200 & 200 \\
\hline Fine wheat bran & - & - & - & 200 & 200 \\
\hline Kaolin & 53.1 & 53.1 & 53.1 & - & - \\
\hline Soybean oil & 32.7 & 32.7 & 32.7 & 32.7 & 32.7 \\
\hline Dicalcium phosphate & 16.0 & 16.0 & 16.0 & 13.2 & 13.2 \\
\hline Limestone & 9.20 & 9.20 & 9.20 & 10.7 & 10.7 \\
\hline Salt & 4.50 & 3.50 & 3.60 & 4.70 & 3.70 \\
\hline L-lysine $\mathrm{HCl}$ & 2.90 & 2.90 & 2.90 & 3.90 & 3.90 \\
\hline L-threonine & 2.20 & 2.20 & 2.20 & 2.60 & 2.60 \\
\hline DL-methionine & 0.20 & 1.20 & 0.20 & - & 1.00 \\
\hline Anhydrous betaine & - & - & 0.90 & - & - \\
\hline Mineral mix ${ }^{2}$ & 0.80 & 0.80 & 0.80 & 0.80 & 0.80 \\
\hline Vitamin $\operatorname{mix}^{3}$ & 0.40 & 0.40 & 0.40 & 0.40 & 0.40 \\
\hline \multicolumn{6}{|c|}{ Calculated chemical composition $\left(\mathrm{g} \mathrm{kg}^{-1}\right)$} \\
\hline Metabolizable energy ( $\mathrm{kcal} \mathrm{kg}^{-1}$ ) & 3,230 & 3,230 & 3,230 & 3,230 & 3,230 \\
\hline Crude protein & 173 & 173 & 173 & 173 & 173 \\
\hline Calcium & 8.00 & 8.00 & 8.00 & 8.00 & 8.00 \\
\hline Total P & 5.50 & 5.50 & 5.50 & 6.50 & 6.50 \\
\hline Available P & 3.70 & 3.70 & 3.70 & 3.70 & 3.70 \\
\hline $\mathrm{Na}$ & 1.80 & 1.80 & 1.80 & 1.80 & 1.80 \\
\hline SID lysine & 11.5 & 11.5 & 11.5 & 11.5 & 11.5 \\
\hline SID methionine & 1.77 & 2.77 & 1.77 & 1.75 & 2.77 \\
\hline SID met + cys & 4.40 & 5.40 & 4.40 & 4.41 & 5.41 \\
\hline SID tryptophan & 1.90 & 1.90 & 1.90 & 1.85 & 1.85 \\
\hline SID threonine & 7.50 & 7.50 & 7.50 & 7.50 & 7.50 \\
\hline SID arginine & 11.1 & 11.1 & 11.1 & 11.1 & 11.1 \\
\hline Choline (mg kg-1) & 1,039 & 1,039 & 1,039 & 1,082 & 1,082 \\
\hline
\end{tabular}

SID - standardized ileal digestible.

${ }^{1} \mathrm{NC}$ - negative control; PC - positive control: $\mathrm{PC}_{\mathrm{Met}}$ - NC supplemented with DL-methionine; $\mathrm{PC}_{\mathrm{Bet}}-\mathrm{NC}$ supplemented with anhydrous betaine; $\mathrm{PC}_{\mathrm{FWB}}$ - formulated with fine wheat bran (FWB); $\mathrm{PC}_{\mathrm{FWB}+\mathrm{Met}}-\mathrm{PC}_{\mathrm{FWB}}$ supplemented with DL-methionine.

${ }^{2}$ Premix should provide at least the following nutrient amounts per kg of feed: Se, $0.39 \mathrm{mg}$; I, $0.46 \mathrm{mg}$; Fe, $52.0 \mathrm{mg}$; $\mathrm{Cu}, 10.4 \mathrm{mg}$; Zn, $104 \mathrm{mg}$; Mn, $39.0 \mathrm{mg}$.

${ }^{3}$ Content per kg of feed: vitamin A, 11,200 IU; vitamin D3, 2,100 IU; vitamin E, $25.2 \mathrm{mg}$; vitamin K, $2.80 \mathrm{mg}$; vitamin B1, $2.24 \mathrm{mg}$; vitamin B2, $7.14 \mathrm{mg}$; vitamin B6, $2.17 \mathrm{mg}$; vitamin B12, $26.6 \mathrm{mg}$; pantotenic acid, $18.2 \mathrm{mg}$; niacin, $36.4 \mathrm{mg}$; folic acid, $0.63 \mathrm{mg}$; biotin, $126 \mathrm{mcg}$.

All data were subjected to one-way analysis of variance (ANOVA). The statistical model included the effect of treatment and block. Means were compared by SNK multiple-range test at a significance level of $\mathrm{P}<0.05$. All statistical analyses were carried out using the Statgraphics Plus version 4.1.

The statistical model used to test the effect of treatments and blocks was:

$$
Y_{i j k}=\mu+T_{i}+B_{j}+\varepsilon_{i j k^{\prime}}
$$

in which $Y_{i j k}$ is the quantitative response variable; $\mu$ is the overall mean; $T$ is the effect of treatment ( $i$ " $=\mathrm{NC}$, $\mathrm{PC}_{\mathrm{Met}} \mathrm{PC}_{\mathrm{Bet}^{\prime}} \mathrm{PC}_{\mathrm{FWB}^{\prime}}$, and $\mathrm{PC}_{\mathrm{FWB}+\mathrm{Met}}$ ); $B$ is the effect of block ( $" j$ " = period 1 and 2); and $\varepsilon$ is the random error. 


\section{Results}

We did not find any differences between experimental treatments for average daily feed intake $(P=0.519)$. However, pigs fed the negative control diet showed lower average daily gain $(P=0.001)$ and higher feed conversion ratio $(\mathrm{P}=0.001)$ than pigs fed the positive control diets (Table 2$)$.

No differences were observed for DCDM $(\mathrm{P}=0.447)$, with average values between experimental treatments ranging from 847 to $859 \mathrm{~g} \mathrm{~kg}^{-1}$ of DM (Table 2). Conversely, DCCE was lower ( $\left.\mathrm{P}=0.001\right)$ when pigs were fed FWB (Table 2).

Digestible energy of feeds $(\mathrm{P}=0.002)$ was higher for FWB diets, while for metabolizable energy $(P=0.033)$, diets formulated with FWB did not differ from those formulated with DL-methionine or anhydrous betaine (Table 2).

Nitrogen intake $(P=0.018)$ and apparently-absorbed nitrogen $(P=0.001)$ were lower when pigs were fed FWB, while nitrogen excreted in feces $(P=0.001)$ was higher (Table 2). Nitrogen retained $(\mathrm{P}=0.023)$ and total nitrogen excreted $(\mathrm{P}=0.223)$ were not significantly affected by FWB inclusion (Table 2). Similary, no effect was observed on net protein utilization $(\mathrm{P}=0.121)$, which corresponds to nitrogen retained:nitrogen intake, as well as on biological value of the feed protein $(\mathrm{P}=0.821)$, which corresponds to nitrogen retained:nitrogen absorbed.

Table 2 - Performance, digestibility of nutrients, and nitrogen balance for growing pigs fed diets supplemented with different methyl donor sources

\begin{tabular}{|c|c|c|c|c|c|c|c|}
\hline \multirow{2}{*}{ Variable } & \multicolumn{5}{|c|}{ Treatment $^{1}$} & \multirow{2}{*}{ P-value } & \multirow{2}{*}{ RMSE } \\
\hline & $\mathrm{NC}$ & $\mathrm{PC}_{\text {Met }}$ & $\mathrm{PC}_{\text {Bet }}$ & $\mathrm{PC}_{\mathrm{FWB}}$ & $\mathrm{PC}_{\mathrm{FWB}+\mathrm{Met}}$ & & \\
\hline Number of pigs & 6 & 6 & 6 & 6 & 6 & & \\
\hline \multicolumn{8}{|l|}{ Performance $\left(\mathrm{kg} \mathrm{day}^{-1}\right)$} \\
\hline ADFI & 1.806 & 1.802 & 1.821 & 1.799 & 1.792 & 0.519 & 29.4 \\
\hline $\mathrm{ADG}$ & $0.872 \mathrm{~b}$ & $1.020 \mathrm{a}$ & $1.017 \mathrm{a}$ & $1.010 \mathrm{a}$ & $1.018 \mathrm{a}$ & 0.001 & 0.055 \\
\hline FCR & $2.08 \mathrm{~b}$ & $1.76 \mathrm{a}$ & $1.79 a$ & $1.78 \mathrm{a}$ & $1.76 \mathrm{a}$ & 0.001 & 0.106 \\
\hline \multicolumn{8}{|l|}{ Digestibility ( $\mathrm{g} \mathrm{kg}^{-1}$ of DM) } \\
\hline Dry matter & 854 & 859 & 847 & 856 & 850 & 0.447 & 1.18 \\
\hline Crude energy & $897 a$ & $908 \mathrm{a}$ & $898 \mathrm{a}$ & $859 b$ & $854 \mathrm{~b}$ & 0.001 & 1.09 \\
\hline \multicolumn{8}{|c|}{ Energy partitioning ( $\mathrm{kcal} \mathrm{kg}^{-1}$ of DM) } \\
\hline $\mathrm{DE}$ & $3,823 \mathrm{c}$ & $3,860 \mathrm{bc}$ & $3,830 \mathrm{c}$ & $3,938 \mathrm{a}$ & $3,902 \mathrm{ab}$ & 0.002 & 48.7 \\
\hline $\mathrm{ME}$ & $3,731 b$ & $3,764 a b$ & $3,738 \mathrm{~b}$ & $3,835 a$ & $3,793 a b$ & 0.033 & 59.4 \\
\hline \multicolumn{8}{|l|}{ Nitrogen balance $\left(\mathrm{g}\right.$ day $^{-1}$ ) } \\
\hline $\mathrm{N}$ intake & $49.6 \mathrm{ab}$ & $49.5 \mathrm{ab}$ & $50.0 \mathrm{a}$ & $48.7 \mathrm{~b}$ & $48.5 \mathrm{~b}$ & 0.018 & 0.810 \\
\hline \multicolumn{8}{|l|}{$\mathrm{N}$ excretion } \\
\hline Fecal & $7.24 \mathrm{~b}$ & $6.19 \mathrm{~b}$ & $7.30 \mathrm{~b}$ & $9.53 a$ & $9.49 \mathrm{a}$ & 0.001 & 1.18 \\
\hline Urinary & 11.2 & 10.6 & 10.5 & 11.1 & 10.3 & 0.961 & 2.67 \\
\hline Total excreted & 18.5 & 16.8 & 17.8 & 20.7 & 19.8 & 0.223 & 3.06 \\
\hline $\mathrm{N}$ retained & 31.2 & 32.7 & 32.3 & 28.1 & 28.8 & 0.023 & 2.74 \\
\hline $\mathrm{N}$ apparently absorbed & $42.4 \mathrm{a}$ & $43.3 \mathrm{a}$ & $42.7 \mathrm{a}$ & $39.2 b$ & $39.0 \mathrm{~b}$ & 0.001 & 0.899 \\
\hline $\mathrm{NPU}\left(\mathrm{g} \mathrm{g}^{-1}\right)$ & 0.629 & 0.669 & 0.650 & 0.580 & 0.594 & 0.121 & 6.41 \\
\hline BVFP $\left(\mathrm{g} \mathrm{g}^{-1}\right)$ & 0.736 & 0.760 & 0.761 & 0.721 & 0.739 & 0.821 & 6.76 \\
\hline
\end{tabular}

DM - dry matter; DE - digestible energy; ME - metabolizable energy; ADFI - average daily feed intake; ADG - average daily gain; FCR - feed conversion ratio; NPU - net protein utilization (N retained/N intake); BVFP - biological value of the food protein ( $\mathrm{N}$ retained/N apparently absorbed); RMSE - root-mean-square error.

${ }^{1} \mathrm{NC}$ - negative control; PC - positive control: $\mathrm{PC}_{\mathrm{Met}}-\mathrm{NC}$ supplemented with DL-methionine; $\mathrm{PC}_{\mathrm{Bet}}-\mathrm{NC}$ supplemented with anhydrous betaine; $\mathrm{PC}_{\mathrm{FWB}}$ - formulated with fine wheat bran (FWB); $\mathrm{PC}$ FWB $+\mathrm{Met}-\mathrm{PC}_{\mathrm{FWB}}$ supplemented with DL-methionine.

Mean values in the same line with different letters differ statistically according to Student-Newman-Keuls test $(\mathrm{P}<0.05)$. 


\section{Discussion}

Even with animals raised in metabolic cages, it is important to cite that pigs fed FWB maintained the same performance-related variables as those fed diets supplemented with DL-methionine and anhydrous betaine. The hypothesis of providing betaine throughout FWB inclusion seems to be supported by our results on performance, since in the $\mathrm{PC}_{\mathrm{FWB}}$ diet, SID Met+Cys requirements were achieved only by adding FWB. The supposed betaine provided by wheat could be used in transmethylation reactions from homocysteine to methionine (Nelson and Cox, 2014), which would maintain the protein synthesis and, thus, performance.

Even though some studies reported that the osmolytic property of betaine supports intestinal cell growth, influencing nutrient digestibility (Xu and Yu, 2000; Eklund et al., 2005), we did not see any improvement by FWB or anhydrous betaine addition. However, in our study, the diet with anhydrous betaine provided the same DCCE as the diet with DL-methionine. This is in line of previous research, that has shown that betaine could be used to methylate homocysteine to reform the amino acid methionine following donation of its methyl group (McDevitt et al., 2000; McBreairty et al., 2016).

In agreement with our findings, Wesendonck et al. (2013), in a study with growing pigs, found that FWB-based diets showed a DCCE 8.49\% lower than a reference diet based on maize and soybean meal. The lower nutrient digestibility of FWB diets could be related to their high dietary fiber levels. It has been shown that the fiber content increases the rate of feed passage, which might decrease nutrient utilization (Noblet and Le Goff, 2001; Lindberg, 2014) and the available energy content of the feed, because the fiber is only partly digested by growing pigs (Noblet and Le Goff, 2001).

Although at a lower digestibility coefficient of crude energy, FWB diets showed GE values numerically higher (average of 4,576 kcal kg-1; not presented) than diets based on maize and soybean meal (average of 4,259 kcal kg-1; not presented). As a consequence, those diets showed higher digestible energy values. Digestible and metabolizable energy of feeds in the present study are in agreement with the values calculated by Wesendonck et al. (2013); feeds with FWB presented 3,660 and 3,550 $\mathrm{kcal} \mathrm{kg}^{-1}$ of $\mathrm{DE}$ and ME, respectively.

The lower nitrogen intake by pigs fed FWB and higher nitrogen excreted in feces could be related to the dietary fiber content in these diets. Although all diets presented the same crude protein content (about $193 \mathrm{~g} \mathrm{~kg}^{-1}$ ), pigs fed FWB diets consumed less feed (though not significant). This could be related to the effect of dietary fiber on viscosity, which decreases the rate of gastric emptying and, consequently, reduces intake (Slavin, 2005). Interestingly, fecal excretion was higher when pigs were fed FWB, which could be a result of the nitrogen associated with cell wall fiber (Van Soest et al., 1991) and can explain the statistical difference for fecal nitrogen, but not for urinary or total excretion.

There is some evidence that dietary betaine supplementation improves nitrogen utilization of pigs (Eklund et al., 2005) due to the higher availability of methionine and cysteine for protein deposition in betaine-supplemented diets (McDevitt et al., 2000). However, no improvement in nitrogen utilization was observed in the present study by betaine addition; nevertheless, the lack of significant differences for the net protein utilization (which express how much of dietary nitrogen was deposited into body tissues) indicated that the nitrogen from diets was used by pigs with the same efficiency, even when betaine was supplied by FWB. The same could be inferred from values of biological value of the feed protein, which correspond to the amount of apparently absorbed nitrogen retained by the organism to build or repair tissues. These results are supported by the lack of differences in performance-related variables among positive control treatments.

\section{Conclusions}

Under the evaluated conditions, the fine wheat bran composition showed $12.0 \mathrm{~g}$ of betaine $\mathrm{kg}^{-1}$, which is available to maintain nitrogen retention and performance of growing pigs. However, fine wheat bran is not an effective source of betaine to maintain energy and dry matter digestibility. 


\section{Acknowledgments}

The authors wish to thank the Coordenação de Aperfeiçoamento de Pessoal de Nível Superior (CAPES), for granting scholarship to the first author and financial support.

\section{References}

AOAC - Association of Official Analytical Chemistry. 1990. Official methods of analysis. 15th ed. AOAC International, Arlington, VA.

ARC - Agricultural Research Council. 1981. The nutrient requirements of pigs. Commonwealth, Slough, UK.

Brosnan, J. T.; Brosnan, M. E.; Bertolo, R. F. P. and Brunton, J. A. 2007. Methionine: a metabolically unique amino acid. Livestock Science 112:2-7. https://doi.org/10.1016/j.livsci.2007.07.005

Campbell, G. L.; Campbell, L. D. and Blair, R. 1983. Calculation of metabolizable energy for ingredients incorporated at low levels into a reference diet. Poultry Science 62:705-707. https://doi.org/10.3382/ps.0620705

Eklund, M.; Bauer, E.; Wamatu, J. and Mosenthin, R. 2005. Potential nutritional and physiological functions of betaine in livestock. Nutrition Research Reviews 18:31-48. https://doi.org/10.1079/NRR200493

Feng, J.; Liu, X.; Wang, Y. Z. and Xu, Z. R. 2006. Effects of betaine on performance, carcass characteristics and hepatic betaine-homocysteine methyltransferase activity in finishing barrows. Asian-Australasian Journal of Animal Sciences 19:402-405. https://doi.org/10.5713/ajas.2006.402

Lindberg, J. E. 2014. Fiber effects in nutrition and gut health in pigs. Journal of Animal Science and Biotechnology 5:15. https://doi.org/10.1186/2049-1891-5-15

McBreairty, L. E.; Robinson, J. L.; Harding, S. V.; Randell, E. W.; Brunton, J. A. and Bertolo, R. F. 2016. Betaine is as effective as folate at re-synthesizing methionine for protein synthesis during moderate methionine deficiency in piglets. European Journal of Nutrition 55:2423-2430.

McDevitt, R. M.; Mack, S. and Wallis, I. R. 2000. Can betaine partially replace or enhance the effect of methionine by improving broiler growth and carcase characteristics? British Poultry Science 41:473-480. https://doi.org/10.1080/713654957

Nelson, D. L. and Cox, M. M. 2014. Amino acids, peptides, and proteins. In: Principles of biochemistry. 6th ed. New York, U. S., Macmillan.

Noblet, J. and Le Goff, G. 2001. Effect of dietary fibre on the energy value of feeds for pigs. Animal Feed Science and Technology 90:35-52. https://doi.org/10.1016/S0377-8401(01)00195-X

Noblet, J. and Shi, X. S. 1993. Comparative digestibility of energy and nutrients in growing pigs fed ad libitum and adult sows fed at maintenance. Livestock Production Science 34:137-152. https://doi.org/10.1016/0301-6226(93)90042-G

Rostagno, H. S.; Albino, L. F. T.; Donzele, J. L.; Gomes, P. C.; Oliveira, R. F.; Lopes, D. C.; Ferreira, A. S.; Barreto, S. L. T. and Euclides, R. F. 2011. Tabelas brasileiras para aves e suínos: Composição dos alimentos e exigências nutricionais. 3.ed. UFV, Viçosa, MG.

Sakomura, N. K. and Rostagno, H. S. 2016. Métodos de pesquisa em nutrição de monogástricos. 2.ed. FUNEP, Jaboticabal.

Slavin, J. L. 2005. Dietary fiber and body weight. Nutrition 21:411-418. https://doi.org/10.1016/j.nut.2004.08.018

Van Soest, P. J.; Robertson, J. B. and Lewis, B. A. 1991. Methods for dietary fiber, neutral detergent fiber, and nonstarch polysaccharides in relation to animal nutrition. Journal of Dairy Science 74:3583-3597. https://doi.org/10.3168/jds. S0022-0302(91)78551-2

Wesendonck, W. R.; Kessler, A. M.; Ribeiro, A. M. L.; Somensi, M. L.; Bockor, L.; Dadalt, J. C.; Monteiro, A. N. T. R.; Marx, F R. 2013. Valor nutricional e energia metabolizável de subprodutos do trigo utilizados para alimentação de suínos em crescimento. Pesquisa Agropecuária Brasileira 48:203-210.

$\mathrm{Xu}, \mathrm{Z}$. R. and Yu, D. Y. 2000. Effect of betaine on digestive function of weaned piglets. Chinese Journal of Veterinary Science 20:201-204.

Zeisel, S. H.; Mar, M. H.; Howe, J. C. and Holden, J. M. 2003. Concentrations of choline-containing compounds and betaine in common foods. Journal of Nutrition 133:1302-1307. https://doi.org/10.1093/jn/133.5.1302 